\title{
Isolation of Aryl Acylamidase-Producing Soil Bacteria and Some Properties of the Extracellular Enzymes*
}

\author{
Toshiie Nakamura, Kazuo Mochida, Wen Xin Li** and Yoshihisa Ozoe \\ Department of Bioresource Science, Faculty of Agriculture, Shimane University, \\ Nishikawatsu, Matsue 690, Japan
}

(Received August 23, 1991; Accepted February 1, 1992)

\begin{abstract}
Soil bacteria producing aryl acylamidases extracellularly were isolated by a convenient method capable of detecting the activity directly on an agar plate where colonies developed, by overlaying successively the agar layers containing substrate acetanilide (AAN) and reagents for coloration by aniline (AN) released. The detection ratio of colonies producing the enzymes was $6 \%$ in Bouillon medium and $13 \%$ in a minimal medium containing AAN as a sole carbon source. In a liquid culture of the most active bacterium, A-1, 69\% of the activity existed in the supernatant of broth and $29 \%$ was remained with sonicated cell debris. The activity of this extracellular enzyme(s) remarkably increased under preincubation with AAN. Among the extracellular enzymes from active colonies isolated with Bouillon medium and the minimal medium, $60 \%$ and $42 \%$ of the enzymes, respectively, were highly activated by AAN. This substrate activation, at least by AAN, seemed fairly general for extracellular aryl acylamidases originated from soil bacteria.
\end{abstract}

\section{INTRODUCTION}

While many microbial hydrolases are essentially intracellular enzymes, extracellular ones are also found in soils associated with cell debris and soil colloids. ${ }^{1)}$ In our previous paper, ${ }^{2)}$ we have shown that such extracellular hydrolases in soil may play an important role in degrading pesticides and preserving the environment. The general conception of extracellular enzymes ${ }^{1,3)}$ and their involvement in pesticide degradation ${ }^{4}$ have been already

* Studies on Soil Aryl Acylamidases (Part 1). The research was supported in part by Grant-inAid for Scientific Research No. 60304026 (19851987) from the Ministry of Education, Science and Culture of Japan.

Major part of this study was presented at the 1989 International Chemical Congress of Pacific Basin Societies (Honolulu, December 1989).

** Present address: Lab. of Agricultural Chemicals, Faculty of Agriculture, Ibaraki University, Amicho, Inashiki-gun, Ibaraki 300-03, Japan. reviewed, but studies on related microbial extracellular hydrolases seem still insufficient. In our studies, microbial aryl acylamidases were taken up because enzymes of bacteria ${ }^{5-16)}$ and fungi ${ }^{17-24)}$ had a broad substrate specificity and their activities were easily induced by various pesticidal acylanilides, carbamates or urea derivatives. This paper reports the isolation of active soil bacteria producing aryl acylamidases and some properties of the extracellular enzymes.

\section{MATERIALS AND METHODS}

\section{Chemicals and Materials}

Acetanilide (AAN), $N$-(1-naphthyl)ethylenediamine dihydrochloride (NED) and tubingseamless 20/32-inch cellophane for dialysis (cellophane tube) were purchased from Wako Pure Chemical. Ehrlich's meat extract and peptone were purchased from Kyokuto Seiyaku Kogyo. Other chemicals and materials were purchased from Wako Pure Chemical or Nakarai Chemicals. Aniline (AN) 
for calibration was used after distillation.

\section{Soils}

Soils were collected from the surface $(5 \mathrm{~cm}$ in depth) of different paddy or upland fields and the A horizon of different forest soils at Shimane University and the neighborhood. The soils were air-dried, sieved with a $2-\mathrm{mm}$ screen and mixed thoroughly before use.

\section{Media}

Bouillon medium: $10 \mathrm{~g}$ of Ehrlich's meat extract, $10 \mathrm{~g}$ of peptone and $5 \mathrm{~g}$ of $\mathrm{NaCl}$ were dissolved in $1 l$ of distilled water.

Minimal medium supplemented with AAN as a sole carbon source: $3.4 \mathrm{~g}$ of $\mathrm{KH}_{2} \mathrm{PO}_{4}, 2.32$ $\mathrm{g}$ of $\mathrm{Na}_{3} \mathrm{PO}_{4}, 1.0 \mathrm{~g}$ of $\left(\mathrm{NH}_{4}\right)_{2} \mathrm{SO}_{4}, 0.2 \mathrm{ml}$ of $5000 \mathrm{ppm}$ AAN aqueous solution and $10.0 \mathrm{ml}$ of mineral solution were dissolved in $1 l$ of distilled water. The mineral solution contained $3.0 \mathrm{~g}$ of $\mathrm{MgSO}_{4}, 0.5 \mathrm{~g}$ of $\mathrm{MnSO}_{4}, 1.0 \mathrm{~g}$ of $\mathrm{NaCl}, 0.1 \mathrm{~g}$ of $\mathrm{CaCl}_{2}, 0.1 \mathrm{~g}$ of $\mathrm{ZnSO}_{4} \cdot 7 \mathrm{H}_{2} \mathrm{O}$, $10 \mathrm{mg}$ of $\mathrm{K}_{2} \mathrm{Al}_{2}\left(\mathrm{SO}_{4}\right)_{4} \cdot 24 \mathrm{H}_{2} \mathrm{O}, 10 \mathrm{mg}$ of $\mathrm{H}_{3} \mathrm{BO}_{4}$ and $10 \mathrm{mg}$ of $\mathrm{Na}_{2} \mathrm{MoO}_{4} \cdot 2 \mathrm{H}_{2} \mathrm{O}$ in $1 l$ of distilled water.

Agar plates for bacterial isolation were prepared by dissolving 1.5 to $2.0 \%$ of agar into Bouillon or minimal medium.

\section{Isolation of Active Bacterial Colonies}

Bacteria were isolated by a conventional soil dilution plate method. One-milliliter portions of serial dilutions from $1 \mathrm{~g}$ of each soil were mixed with $9 \mathrm{ml}$ of Bouillon or minimal agar medium liquefied at $45^{\circ} \mathrm{C}$ in a $9-\mathrm{cm}$ petri dish and incubated at $30^{\circ} \mathrm{C}$ for 5 days.

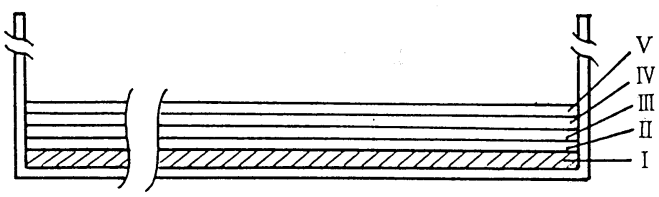

Fig. 1 Multiple agar layers method for detection of bacterial colonies producing aryl acylamidases.

I: Soil dilution agar plate developing colonies (thickness; ca. $1.7 \mathrm{~mm}$ ), II, III, IV and V: Agar layers containing substrate $\mathrm{AAN}, \mathrm{NaNO}_{2}$, sulfamic acid and NED, respectively (each thickness; ca. $1 \mathrm{~mm}$ ).
Active colonies were detected by a multiple agar layers method in which agar layers containing AAN and reagents were overlaid successively for coloration by released $\mathrm{AN}$ by modifying the diazotization and coupling method, ${ }^{25)}$ as shown in Fig. 1. To an agar plate where bacterial colonies were developing, $1 \mathrm{ml}$ of $37 \mathrm{~mm}(5000 \mathrm{ppm}) \mathrm{ANN}$ and $5 \mathrm{ml}$ of $2 \%$ agar (liquefied at $50^{\circ} \mathrm{C}$ ) were added and mixed gently to overlay a homogeneous layer. The plate was then incubated at $30^{\circ} \mathrm{C}$ for 3 to $4 \mathrm{hr}$. In a similar manner, the layer of $1 \mathrm{ml}$ of $0.2 \% \mathrm{NaNO}_{2}$ in $20 \%$ tartaric acid and $5 \mathrm{ml}$ of $2 \%$ agar, after $10 \mathrm{~min}$, the layer of $1 \mathrm{ml}$ of $0.2 \%$ sulfamic acid in $20 \%$ tartaric acid and $5 \mathrm{ml}$ of $2 \%$ agar, and after another $15 \mathrm{~min}$, the layer of $1 \mathrm{ml}$ of $0.2 \% \mathrm{NED}$ in $20 \%$ tartaric acid and $5 \mathrm{ml}$ of $2 \%$ agar were overlaid on the plate, which was left standing at room temperature until an appropriate color (purplish red) developed around active colonies.

The active bacterial colonies isolated were stored on Bouillon agar slants at $5{ }^{\circ} \mathrm{C}$.

\section{Liquid Culture and Crude Enzyme Prepara- tion}

Active bacteria were inoculated in $10 \mathrm{ml}$ of Bouillon medium and precultured on standing at $30^{\circ} \mathrm{C}$ for 3 to 5 days. Precultured broth $(10 \mathrm{ml})$ was added into 250 or $2500 \mathrm{ml}$ of Bouillon medium in a $500-\mathrm{ml}$ flat bottom flask or a 5-l Erlenmeyer flask, and the broth was incubated on standing at $30^{\circ} \mathrm{C}$ for 9 days with occasional stirring. The bacterial growth was followed by measuring the absorbance at $550 \mathrm{~nm}$. Crude enzyme preparation was made up by centrifuging the broth at $8000 \mathrm{rpm}$ at $0^{\circ} \mathrm{C}$ for $20 \mathrm{~min}$, followed by dialysis against water in order to remove inhibitory substances; each $10 \mathrm{ml}$ of the supernatant packed in a cellophane tube was dialyzed against $2 l$ of distilled water at $5^{\circ} \mathrm{C}$ for $24 \mathrm{hr}$ with gentle stirring. This inner solution was employed as crude enzyme preparation.

\section{Assay of Aryl Acylamidase Activity}

AAN was used as a substrate, and AN released during incubation for 2.0 to $6.0 \mathrm{hr}$ was determined by the diazotization and coupling method $^{25)}$ as follows: One milliliter of the crude enzyme preparation was mixed with 1.0 
$\mathrm{ml}$ of $0.1 \mathrm{~m} \mathrm{Na-phosphate} \mathrm{buffer}(\mathrm{pH} 7.4)$ and $2.0 \mathrm{ml}$ of $37 \mathrm{~mm} \mathrm{AAN}$ in a test tube, and the reaction mixture was incubated at $25^{\circ} \mathrm{C}$ or $30^{\circ} \mathrm{C}$ for a definite time with reciprocal shaking. To the mixture, $1.0 \mathrm{ml}$ of $1 \mathrm{~N} \mathrm{HCl}, 4.2 \mathrm{ml}$ of distilled water and $0.2 \mathrm{ml}$ of $2 \% \mathrm{NaNO}_{2}$ were added. After standing for $5 \mathrm{~min}$ with occasional stirring, $0.2 \mathrm{ml}$ of $10 \%$ sulfamic acid was added, and the mixture was left standing for $10 \mathrm{~min}$ with occasional stirring. After $0.4 \mathrm{ml}$ of $1 \%$ NED was added, the mixture was allowed to stand for another $2.0 \mathrm{hr}$. Released AN was estimated colorimetrically by measuring the absorbance at $550 \mathrm{~nm}$.

\section{Localization of Enzyme Activity}

Ten milliliters of liquid-cultured broth was centrifuged at $15,000 \mathrm{rpm}$ at $0^{\circ} \mathrm{C}$ for $15 \mathrm{~min}$. The precipitated cells were redispersed in 10 $\mathrm{ml}$ of distilled water and destructed 10 times for $1 \mathrm{~min}$ each at $38 \mathrm{kHz}$ with an ultrasonication apparatus (Kaijo Denki, T-A 4280). The suspension was centrifuged again, and the precipitate was redispersed in $10 \mathrm{ml}$ of distilled water. Enzyme activity in each supernatant and suspension was assayed as mentioned above.

\section{Activation of Crude Enzymes}

Ten milliliters of the crude enzyme preparation packed into a cellophane tube was immersed into $2 l$ of $18.5 \mathrm{~mm} \mathrm{AAN} \mathrm{at} 5^{\circ} \mathrm{C}$ for $96 \mathrm{hr}$ with gentle stirring. The inner solution was dialyzed twice against $2 l$ of distilled water at $5^{\circ} \mathrm{C}$ for $12 \mathrm{hr}$ each with gentle stirring in order to remove $\mathrm{AAN}$ and/or AN. It was later used as activated enzyme preparation.

\section{RESULTS AND DISCUSSION}

\section{Isolation of Active Bacteria}

In order to detect active bacterial colonies capable of producing aryl acylamidases, a multiple agar layers method was devised. The zone around active colonies turned purplish red. This method was found very convenient and advantageous for isolating active colonies producing enzymes extracellularly, although coloration by AN excreted from cells might be partly included.

Isolation was done by using Bouillon medium and minimal medium containing AAN as a sole carbon source. The detection ratios of active colonies against the total colonies are shown in Table 1. Although the number of total colonies was greater in the Bouillon medium than in the minimal medium, the detection ratios in the latter were approximately twice those in the former (ca. 13\% vs. ca. 6\%). Active bacteria were present in almost all the soils. Several colonies showing relatively high activity were stored on Bouillon medium slants at about $5^{\circ} \mathrm{C}$.

\section{Enzyme Excretion from Bacterial Cells}

By employing the most active bacterium A-1, enzyme production and localization in a liquid culture were examined in Bouillon medium and minimal medium.

Table 1 Detection ratio of active bacterial colonies capable of hydrolyzing AAN as a substrate.

\begin{tabular}{|c|c|c|c|c|c|c|c|c|}
\hline \multirow{3}{*}{ Soil } & \multicolumn{8}{|c|}{ Active colonies/Total colonies ( $\%)$} \\
\hline & \multicolumn{4}{|c|}{ Bouillon medium } & \multicolumn{4}{|c|}{ Minimal medium ${ }^{a}$ ) } \\
\hline & 1 & 2 & 3 & Av. & 1 & 2 & 3 & Av. \\
\hline \multirow[t]{2}{*}{ Paddy soil } & 6.5 & 8.5 & 4.1 & 6.4 & 14.3 & 27.7 & 17.2 & 19.7 \\
\hline & 12.5 & 11.1 & 2.6 & 8.7 & 22.2 & 20.0 & 11.8 & 18.0 \\
\hline \multirow{2}{*}{$\begin{array}{l}\text { Upland soil } \\
(2\end{array}$} & 2.5 & 0 & 11.1 & 4.5 & 6.3 & 11.8 & 5.5 & 7.9 \\
\hline & 7.4 & 5.3 & 0 & 4.2 & 7.4 & 14.3 & 4.2 & 8.6 \\
\hline \multirow{2}{*}{ Forest soil } & 13.8 & 3.1 & 7.4 & 8.1 & 14.8 & 21.4 & 9.1 & 15.3 \\
\hline & 2.9 & 7.3 & 1.9 & 4.0 & 4.2 & 7.7 & 6.3 & 6.1 \\
\hline Total av. & & & & 6.0 & & & & 12.6 \\
\hline
\end{tabular}

a) Containing $1.0 \mathrm{ppm}$ AAN as a sole carbon source and mineral salts. 
Both bacterial growth and enzyme production were satisfactory in the Bouillon medium, while those in the minimal medium were poor. Enzyme activity in a cultured broth, however, increased remarkably by dialyzing the broth against water or phosphate buffer ( $\mathrm{pH} 7.4)$ with or without mercaptoethanol, suggesting that one or another inhibitory substance might exist in the broth, although it was left unidentified. The activity reached maximum after dialyzing for $24 \mathrm{hr}$ and decreased thereafter, as shown in Fig. 2. The activity before and after dialysis is shown in Table 2. The broth supernatant after dialysis against water was employed as crude enzyme preparation thereafter.

The bacterium A-1 was cultured in Bouillon medium. The bacterial growth in the broth and the activity of crude enzyme preparation are shown in Fig. 3. The enzyme was excreted from bacterial cells into the broth, and

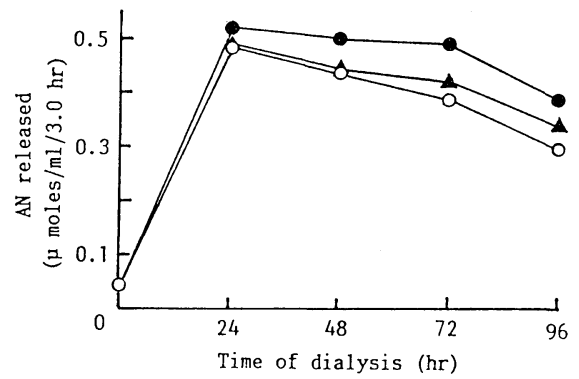

Fig. 2 Effect of dialysis with a cellophane tube on the enzyme activity in a liquid culture broth of bacterium A-1.

Dialyzed against distilled water (O), $0.02 \mathrm{M}$ phosphate buffer ( $\mathrm{pH} 7.4)(\bullet)$, and $0.02 \mathrm{~m}$ phosphate buffer ( $\mathrm{pH} 7.4$ ) containing $10 \mathrm{~mm}$ mercaptoethanol $(\mathbf{A})$.

Table 2 Increase of the enzyme activity in a liquid culture broth ${ }^{a}$ ) by dialyzing against water.

\begin{tabular}{ccc}
\hline \multirow{2}{*}{$\begin{array}{c}\text { Active } \\
\text { colony }\end{array}$} & \multicolumn{2}{c}{$\begin{array}{c}\text { Activity (Released AN, } \\
\mu \mathrm{mol} / \mathrm{ml} / 3 \mathrm{hr})\end{array}$} \\
\cline { 2 - 3 } & Before dialysis & After dialysis \\
\hline A-1 & 0.04 & 0.90 \\
A-2 & 0.01 & 0.86 \\
A-3 & 0.01 & 0.76 \\
A-4 & 0.02 & 0.62 \\
\hline
\end{tabular}

a) Preculture broths were employed. the activity reached nearly equilibrium on the 9th day although the bacterial growth declined.

Activity distribution in the broth supernatant and cells was examined in order to confirm the localization of enzyme(s); $69 \%$ of the activity existed in the supernatant and ca. $29 \%$ remained with the sonicated cell debris, as shown in Table 3. These results suggested that the enzyme might exist originally associated with the cell wall, although it was easily excreted from living cells and released from lysed cells.

\section{Properties of Enzyme from Bacterium A-1}

The A-1 was found to belong taxonomically to the Coryneform group of bacteria. The details will be presented in our next paper.

Crude enzyme preparation from bacterium A-1 was prepared by dialyzing a liquid-cultured broth against water and stored at about $5^{\circ} \mathrm{C}$. Although an induction period in enzyme

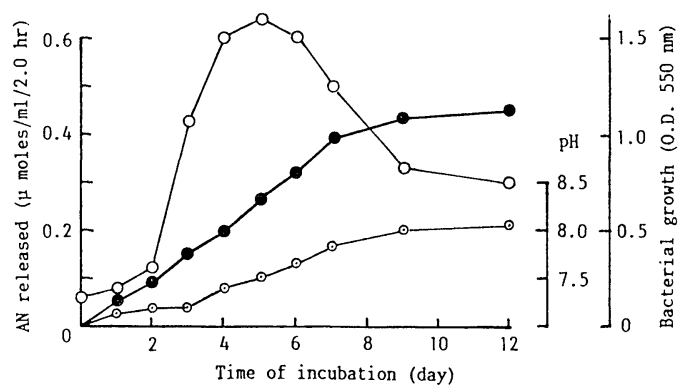

Fig. 3 Growth of bacterium A-1 and the enzyme activity excreted into broth in a liquid culture with Bouillon medium.

$\bigcirc$ : Growth of bacterium A-1. $\odot: ~ p H$ of the cultured broth. $\bullet$ : Enzyme activity (released $\mathrm{AN}, \mu \mathrm{mol} / \mathrm{ml} / 2 \mathrm{hr}$ ) in the broth supernatant after dialysis against water.

Table 3 Localization of the enzyme in a liquid culture of bacterium A-1.

\begin{tabular}{ccc}
\hline Part & Activity $\left.^{\mathrm{a}}\right)$ & (Ratio, \%) \\
\hline Supernatant of broth & 4.86 & $(69.0)$ \\
Bacterial cells & 1.28 & $(31.0)$ \\
Sonicated cell debris & 1.24 & $(28.7)$ \\
Extract from cells & 0.10 & $(2.6)$ \\
\hline
\end{tabular}

a) Released $\mathrm{AN}, \mu \mathrm{mol} / \mathrm{ml} / 6 \mathrm{hr}$. 
reaction was found to be 1 to $2 \mathrm{hr}$, there was a good linear correlation between the amount of added enzyme preparation and the amount of AN released during the 5-hr incubation.

The optimal $\mathrm{pH}$ and temperature in enzyme reaction were about 7.0 and $25^{\circ} \mathrm{C}$, respectively. The enzyme(s) was stable in the $\mathrm{pH}$ range of 6 to 8.5 , but unstable in incubation $(1 \mathrm{hr})$ at over $30^{\circ} \mathrm{C}$; about three-fourths of the activity was lost at $35^{\circ} \mathrm{C}$. The effects of metal ions and EDTA on the activity are shown in Table 4. The enzyme(s) was not affected by $\mathrm{Mn}^{2+}$ but strongly inhibited by $\mathrm{Co}^{2+}, \mathrm{Mg}^{2+}$ and $\mathrm{Fe}^{2+}$. Among sulfhydryl inhibitors, $\mathrm{Ag}^{2+}$ was very effective, while $\mathrm{Cu}^{2+}$ only slightly. EDTA, a chelating agent, was also very inhibitory, suggesting that a certain metal ion might play an important role in enzyme reaction. Effects of cations such as $\mathrm{Li}^{+}, \mathrm{K}^{+}$and $\mathrm{Ca}^{2+}$ were not so remarkable.

The induction period in enzyme reaction did not disappear in optimal conditions, but it shortened when the enzyme(s) were preincubated with substrate AAN (9.25 mm) at room temperature for $6 \mathrm{hr}$. The activity remarkably increased.

This substrate activation was followed by preincubation of the enzyme(s) with a higher concentration of AAN at a lower temperature; the enzyme solution was packed with $18.5 \mathrm{~mm}$ (2500 ppm) AAN in a cellophane tube and

Table 4 Effect of metal ions and EDTA on the activity of crude enzyme A-1.

\begin{tabular}{lcc}
\hline & \multicolumn{2}{c}{ Relative activity $(\%)$} \\
\cline { 2 - 3 } Chemical & \multicolumn{2}{c}{ Concentration } \\
\cline { 2 - 3 } & $0.25 \mathrm{mM}$ & $2.5 \mathrm{~mm}$ \\
\hline None & 100 & 100 \\
$\mathrm{MnCl}_{2}$ & 100 & 104 \\
$\mathrm{ZnSO}_{4}$ & 89 & 16 \\
$\mathrm{CoCl}_{2}$ & 3 & 2 \\
$\mathrm{MgCl}_{2}$ & 7 & 7 \\
$\mathrm{FeCl}_{2}$ & 8 & 5 \\
$\mathrm{AgNO}_{3}$ & 3 & 5 \\
$\mathrm{CuCl}_{2}$ & 89 & 85 \\
$\mathrm{KCl}_{\mathrm{CaCl}_{2}}$ & 100 & 122 \\
$\mathrm{Li}_{2} \mathrm{SO}_{4}$ & 89 & 96 \\
$\mathrm{EDTA}$ & 85 & 78 \\
& 3 & 3 \\
\hline
\end{tabular}

immersed in $18.5 \mathrm{~mm}$ AAN solution at $5^{\circ} \mathrm{C}$ with gentle stirring, and the activity was assayed after dialysis against water to remove AAN. For comparison, enzyme solution without AAN was packed and immersed in a same

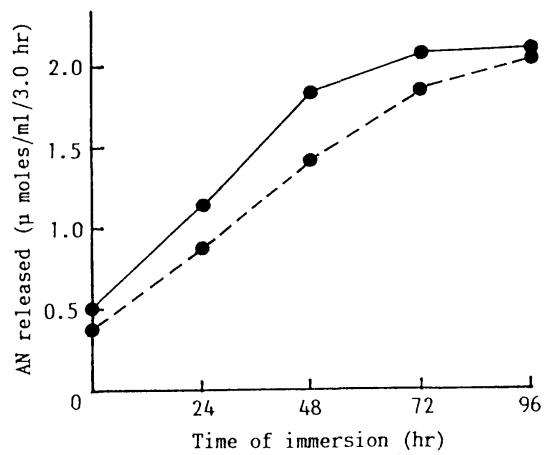

Fig. 4 Activation of the enzyme from bacterium A-1 with substrate AAN.

A crude enzyme preparation with (- -) or without (- - -) $18.5 \mathrm{~mm} \mathrm{AAN} \mathrm{was} \mathrm{packed} \mathrm{in} \mathrm{a}$ cellophane tube and immersed in $18.5 \mathrm{~mm}$ AAN solution at $5^{\circ} \mathrm{C}$ with gentle stirring. Activity was assayed after dialysis against water for removing AAN.

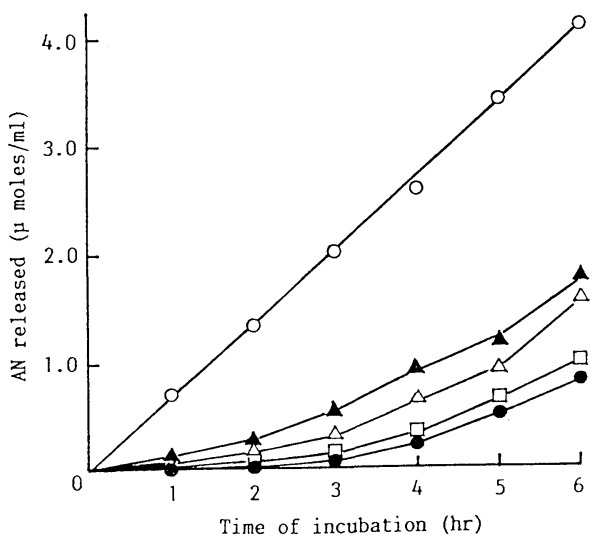

Fig. 5 Effect of substrate AAN and metabolites $\mathrm{AN}$ and/or Na-acetate on activity of the enzyme from bacterium A-1.

A crude enzyme preparation (๑) was packed in a cellophane tube and immersed in $18.5 \mathrm{~mm}$ solution of $\operatorname{AAN}(\bigcirc), \operatorname{AN}(\mathbf{\Delta})$, Na-acetate $(\triangle)$ or both $\mathrm{AN}$ and $\mathrm{Na}$-acetate $(\square)$ for $96 \mathrm{hr}$ at $5^{\circ} \mathrm{C}$ with gentle stirring. Activity was assayed after dialysis against water for removing AAN. 


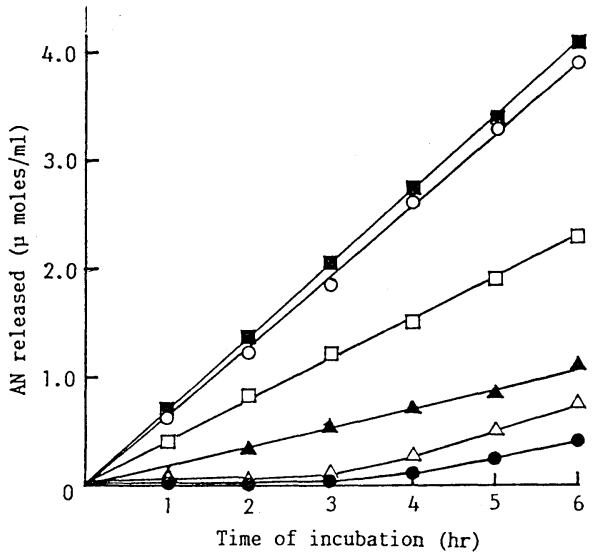

Fig. 6 Influence of AAN concentration on the activation of the enzyme from bacterium A-1.

A crude enzyme preparation packed in a cellophane tube was immersed in AAN solutions of $0(\bullet), 0.74(\triangle), 3.7(\mathbf{\Delta}), 7.4(\square), 18.5(\bigcirc)$ and $37.0 \mathrm{~mm}(\mathbf{\square})$ for $76 \mathrm{hr}$ with gentle stirring. manner as above. The activity equivalently reached maximum after preincubation for $96 \mathrm{hr}$ in both cases, as shown in Fig. 4, and so the latter method was employed thereafter. The enzyme activity remarkably increased after activation treatment, and the lag time disappeared completely, as shown in Fig. 5.

The effects of AN and/or Na-acetate (18.5 $\mathrm{mm}$ ) as metabolites were minor (Fig. 5). Moreover, the effect of AAN concentration on activation reached nearly maximum at 18.5 mM, as shown in Fig. 6.

\section{Substrate Activation of Enzymes from Soil Bacteria}

Since it became of interest whether the above-mentioned substrate activation occurs generally for aryl acylamidases originated from soil bacteria, the active bacterial colonies were isolated again from various soils for activation test with crude enzyme preparations.

Table 5 Typical patterns for the activation with substrate AAN on the crude enzymes from active soil bacteria.

\begin{tabular}{|c|c|c|c|c|c|c|c|c|}
\hline \multirow{4}{*}{ Type ${ }^{c}$} & \multicolumn{4}{|c|}{ Isolates from Bouillon medium } & \multicolumn{4}{|c|}{ Isolates from minimal medium ${ }^{a}$ ) } \\
\hline & \multirow{3}{*}{$\begin{array}{l}\text { Colony } \\
\text { No. }{ }^{d}\end{array}$} & \multicolumn{2}{|c|}{ Activity $\left.{ }^{b}\right)$} & \multirow[b]{3}{*}{$\left.(b / a)^{e}\right)$} & \multirow{3}{*}{$\begin{array}{l}\text { Colony } \\
\text { No. }^{\text {d) }}\end{array}$} & \multicolumn{2}{|c|}{ Activity $\left.^{b}\right)$} & \multirow[b]{3}{*}{$\left.(b / a)^{\mathrm{e}}\right)$} \\
\hline & & before $(a)$ & $\operatorname{after}(b)$ & & & before $(a)$ & $\operatorname{after}(b)$ & \\
\hline & & \multicolumn{2}{|c|}{ activation } & & & \multicolumn{2}{|c|}{ activation } & \\
\hline \multirow{3}{*}{$\mathrm{I}$} & $3 \mathrm{P}$ & 0.07 & 6.25 & 91.0 & $7 \mathrm{P}$ & 0.18 & 6.40 & 35.5 \\
\hline & $19 \mathrm{U}$ & 0.08 & 2.70 & 33.7 & $15 \mathrm{U}$ & 0.03 & 1.94 & 64.7 \\
\hline & $30 \mathrm{~F}$ & 0.09 & 3.10 & 34.5 & $28 \mathrm{~F}$ & 0.09 & 3.74 & 41.6 \\
\hline \multirow{3}{*}{$\mathrm{I}^{\prime}$} & $10 \mathrm{P}$ & 0.32 & 3.15 & 9.9 & $19 \mathrm{U}$ & 0.18 & 1.38 & 7.7 \\
\hline & $18 \mathrm{U}$ & 0.25 & 2.10 & 8.4 & $17 \mathrm{U}$ & 0.27 & 2.04 & 7.6 \\
\hline & $27 \mathrm{~F}$ & 0.25 & 2.00 & 8.0 & $31 \mathrm{~F}$ & 0.33 & 2.50 & 7.6 \\
\hline \multirow{3}{*}{ II } & $2 \mathrm{P}$ & 1.13 & 4.10 & 3.6 & $11 \mathrm{P}$ & 1.06 & 1.50 & 1.4 \\
\hline & $8 \mathrm{P}$ & 1.80 & 2.10 & 1.2 & $12 \mathrm{U}$ & 0.76 & 1.80 & 2.4 \\
\hline & $11 \mathrm{U}$ & 0.83 & 2.70 & 3.3 & $29 \mathrm{~F}$ & 0.97 & 1.74 & 1.8 \\
\hline \multirow{3}{*}{ III } & $9 \mathrm{P}$ & 0.19 & 0.44 & 2.3 & $2 \mathrm{P}$ & 0.05 & 0.14 & 2.9 \\
\hline & $14 \mathrm{U}$ & 0.19 & 0.60 & 3.2 & $5 \mathrm{P}$ & 0.14 & 0.31 & 2.2 \\
\hline & $29 \mathrm{~F}$ & 0.37 & 0.74 & 2.0 & $14 \mathrm{U}$ & 0.17 & 0.58 & 3.4 \\
\hline
\end{tabular}

a) Containing $0.1 \mathrm{ppm} \mathrm{AAN}$ and mineral salts.

b) Released AN, $\mu \mathrm{mol} / \mathrm{ml} / 5.5 \mathrm{hr}$.

c) I: Low initial activity \& extremely high activation ratio, I': Low initial activity \& remarkably high activation ratio, II: Rather high initial activity \& low activation ratio, III: Low initial activity \& low activation ratio.

d) P: Paddy soil, U: Upland soil, F: Forest soil.

e) Activation ratio (-fold) 
Table 6 Appearance ratios of different types of the activation with substrate AAN in the crude enzymes from active soil bacteria.

\begin{tabular}{lllll}
\hline \multirow{2}{*}{$\begin{array}{c}\text { Medium for isolation } \\
\text { of bacteria }\end{array}$} & \multicolumn{4}{c}{ Type of the activation } \\
\cline { 2 - 5 } & I & I' $^{\prime}$ & II & III \\
\hline Bouillon medium & 38 & 22 & 13 & $27 \%$ \\
Minimal medium & 17 & 25 & 25 & 33 \\
\hline \hline
\end{tabular}

\begin{tabular}{lllll}
\hline \hline $\begin{array}{l}\text { Parameters for the type } \\
\text { classification }\end{array}$ & & & \\
\hline $\begin{array}{l}\text { Initial activity } \\
\text { Activation ratio }\end{array}$ & - & - & $>0.5$ & $<0.5$ \\
Activa $^{\text {a }}$ & $>10$ & $10-5$ & $<5$ & $<5$ \\
\hline
\end{tabular}

a) Released $\mathrm{AN}, \mu \mathrm{mol} / \mathrm{ml} / 5.5 \mathrm{hr}$.

b) -fold.

All enzymes were activated more or less by $\mathrm{AAN}$, and the activation patterns were classified into four types as shown in Table 5 . Type I was characterized by bacteria excreting enzymes with a low initial activity and an extremely high activation ratio and type $\mathrm{I}^{\prime}$, with a low initial activity and a remarkably high activation ratio. Type II belonged to bacteria excreting enzymes with a fairly high initial activity and a low activation ratio and type III, low in both parameters.

Appearance ratios of each type of bacterial colonies are in Table 6 , in which tentative parameter values for the classification are shown. At least, enzymes which belong to types I and I' seemed to be activated by AAN. Total appearance ratios of types $\mathrm{I}$ and $\mathrm{I}^{\prime}$ reached $60 \%$ among isolates with the Bouillon medium and $42 \%$ among ones with the minimal medium.

Our study showed: a large number of bacteria extracellularly producing aryl acylamidases similar to those from bacterium A-1 were present in soil; in other words, substrate AAN generally activated extracellular enzymes from soil bacteria. The mechanism of activation may be the induced-fit of the enzymes to the substrate.

\section{REFERENCES}

1) R. G. Burns: Soil Biol. Biochem. 14, 423 (1982)

2) T. Nakamura, K. Mochida, Y. Ozoe, S. Ukawa, M. Sakai \& S. Mitugi: J. Pesticide Sci. 15, 593 (1990)
3) J. Skujins: Crit. Rev. Microbiol. 4, 383 (1976)

4) R. G. Burns \& J. A. Edwards: Pestic. Sci. 11, 506 (1980)

5) P. C. Kearney: J. Agric. Food Chem. 13, 561 (1965)

6) P. C. Kearney \& D. D. Kaufman: Science 147, 740 (1965)

7) P. R. Wallnöfer \& J. Bader; Appl. Microbiol. 19, 714 (1970)

8) G. Engelhardt, P. R. Wallnöfer \& R. Plapp: Appl. Microbiol. 22, 284 (1971)

9) G. Engelhardt, P. R. Wallnöfer \& R. Plapp: Appl. Microbiol. 26, 709 (1973)

10) D. D. Kaufman \& J. Blake: Soil Biol. Biochem. 5, 297 (1973)

11) J. Alt \& K. Krisch: J. Gen. Microbiol. 87, 260 (1975)

12) J. Alt, E. Heymann \& K. Krisch: Eur. J. Biochem. 53, 357 (1975)

13) P. M. Hammond, C. P. Price \& M. D. Scawen: Eur. J. Biochem. 132, 651 (1983)

14) D. Vega, J. Bastide \& C. Coste: Soil Biol. Biochem. 17, 541 (1985)

15) J. L. Marty, T. Khafif, D. Vega \& J. Bastide: Soil Biol. Biochem. 18, 649 (1986)

16) J. L. Marty \& J. Vouges: Agric. Biol. Chem. 51, 3287 (1987)

17) N. E. Sharabi \& L. M. Bordeleau: Appl. Microbiol. 18, 369 (1969)

18) R. P. Lanzilotta \& D. Pramer: Appl. Microbiol. 19, 301 (1970)

19) R. P. Lanzilotta \& D. Pramer: Appl. Microbiol. 19, 307 (1970)

20) S. J. L. Wright \& A. Forey: Soil Biol. Biochem. 4, 207 (1972)

21) D. D. Kaufman \& J. Blake: Soil Biol. Biochem. 5, 297 (1973)

22) J. Blake \& D. D. Kaufman: Pestic. Biochem. Physiol. 5, 305 (1975)

23) P. R. Wallnöfer, G. Tillmanns \& G. Engelhardt: Pestic. Biochem. Physiol. 7, 481 (1977)

24) A. Hiramatsu, S. Yasumoto, O. Komada \& T. Akatsuka: Agric. Biol. Chem. 46, 1751 (1982)

25) T. Nakamura: J. Agric. Chem. Soc. Jpn. 39, 227 (1965) (in Japanese)

\section{要 約}

\section{Aryl acylamidase 産生土壤細菌の分離および産 生菌体外酵素の性質}

中村利家, 持田和男, 李 文新, 尾添嘉久

Aryl acylamidases を産生する土壤細菌を，まずコ ロニー形成培地上に基質 acetanilide (AAN) を含む寒 天層を重ねて培養し, 次いで生成 aniline (AN) の反応. 
呈色用試薬類を含む寒天層を逐次重層する簡便法で分離 した．活性を示すコロニーの検出率は，ブイヨン培地で は $6 \%$ であったが，炭素源として ANN のみを合む最 少培地では $13 \%$ であった．最大活性を示した A-1 菌 の液体培養で，活性の $69 \%$ が培地中に存在し，29\%が 破壊菌体膜中に残ることを確かめた．その菌体外酵素の 性質を検討する過程で，基質 ANNによる前処理で活性
が著しく増大されることがわかったまた，ブイヨンお よび最少培地で再分離した活性細菌のそれぞれ 60 およ び $42 \%$ からの菌体外酵素が AAN 前処理で顕著な活性 増大を示した。 土堙細菌由来の aryl acylamidases で は，この基質活性化はかなり一般的な現象と思われた。

* 土塤 aryl acylamidases に関する研究（第 1 報） 